(C) 1983 ISIJ

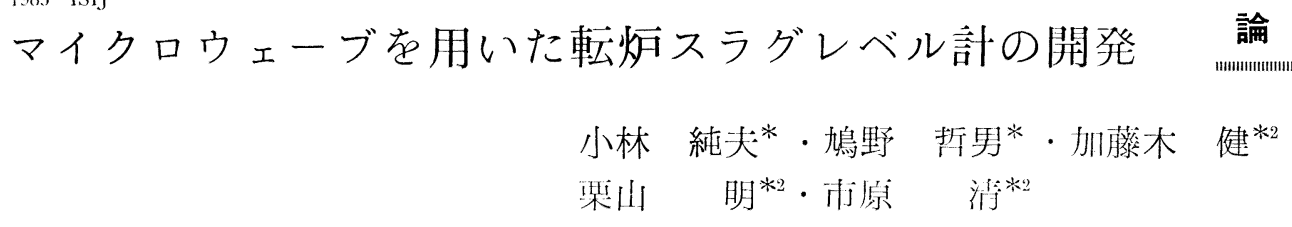

\title{
Slag Level Gauge Using Microwaves in BOF
}

\author{
Sumio Kobayashi, Akio Hatono, Ken Katogi \\ Akira KurIYAMA, and Kiyoshi ICHIHARA
}

\begin{abstract}
Synopsis :
A microwave method to measure directly the level and the reflectivity of the slag in a BOF has been developed, and successfully tested in a 150 ton BOF process. The measurement system is based on the FM radar technique. The results show that this method can be applied to predict slopping, and estimate the slag formation. Most of sloppings are observed when the slag level exceeds a certain critical limit and the reflectivity decreases under a certain level. Slopping predection criteria have been established after a series of measurements. Using the criteria, the slopping is predicted with a reliability of over $80 \%$ within $30 \mathrm{~s}$ before the event. The slopping control scheme using the microwave method has been established and the frequency of the slopping has been decreased to $1 / 5$ of the uncontrolled heat. The microwave system is now in on-line operation at Wakayama Works of Sumitomo Metal Industries.
\end{abstract}

\section{1. 緒}

\section{言}

転炉吹錬においては，脱燐，脱硫などのスラグ-鋼浴

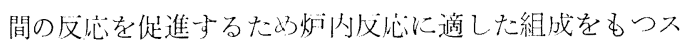
ラグを形成させる必要がある。スラグー鋼浴間の反応は 装入石灰の溸化速度に大きく影響され，石灰の溶解はス

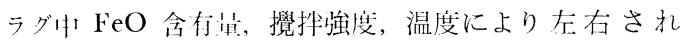
る.

通常, 送酸流㫣, ランス高さの調整により, 石灰の涬 化を適正に抗こなわせるように吹鍊されるが，スラグの 流動性，吹鍊条件により，過度にスラグの泡立ち（スラ グフォーミング : Slag foaming) が起こり, 粒鉄を含ん だスラグが炬外に飛散するスロッピング (Slopping) を 発生する場合がある。スロッピングの発生は, 転炉操業 の妨げとなるばかりでなく，スラグの吐出に伴い溶鋼も 炉外に持ち出されるため, 歩留りの低下を招くことにな る.このため, 転炉内のスラグフォーミング状況を計測 しスロッピングを子知することは重要な課題である.

スロッピングの予知方法としては，転炉音響1) 3)， ラ ンス振動4) 等より転炏内大ラグレベルを閒接的に推定す る方法が報告されている. それに対して, 本報告では転
炉内スラグレベルを直接的に胡測する方法として, マイ クロ波を用いるう法を開発し，当社和歌山製鉄所 $150 \mathrm{t}$ 転炉に打いて武験ならびにォンライン使用を打こなつ た.

スロッピングの子知，防止例御につき良好な結果を得 たので報告する。

\section{2. 測 定 方 法}

\section{1 測定原理}

マイクロ波による転炉大ラグフォーミングレベル測定 装置の機能は，1）スラグレベルの測定，2）スラグ反射 率の測定の 2 点である. スラグレベルの測定は FM レ ーダの原理 ${ }^{5)}$ に基づく (FM : Frequency Modulation : 周波数変調).

Fig. 1 の垁線に示すような，時間とともに周波数が 直線的に変化する波をアンテナより送信する，距離 $x$ の ところに反射体があると, 反射波は時間 $T=2 x / c$ 後に もどつてくるから，その周波数は破線のようになる.

ここで, 送信波の電生波形 $v_{t}$ を

$$
v_{t}=V_{t} \cos 2 \pi\left(f_{0} t+\dot{f}_{0} t^{2} / 2\right) \cdots
$$

と表すと, 受信波の電压波形 $v_{r}$ は,

㽞和 56 年: 4 月本会講演大会にて発表 㽞和 57 年 1 月 8 日受付 (Received Jan. 1982)

* 住友金属工栄(株) 巾块技術研究所 (Central Research Laboratories, Sumitomo Metal Industries, Ltd., 1-3 Nishinagasuhondori Amagasaki 660)

*2 住友金属工策(株) 和歌山製鉄诉 (Wakayama Steel Works, Sumitomo Metal Industries, Ltd.) 


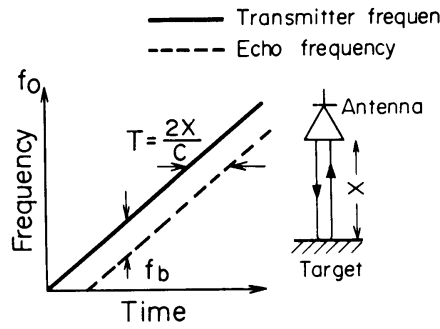

Fig. 1. Principle of the FM radar.

$$
v_{r}=V_{r} \cos 2 \pi\left(f_{0}(t-T)+\dot{f}_{0}(t-T)^{2} / 2\right) \cdot
$$

となり，両者をミキサにより混合すると，次式で示され るらなり信号 vo を得る。

$$
\begin{aligned}
v_{b} & =k V_{t} V_{r} \cos 2 \pi\left(\dot{f}_{0} T t+f_{0} T-\dot{f}_{0} T^{2} / 2\right) \\
& \simeq k V_{t} V_{r} \cos 2 \pi\left(\dot{f}_{0} T t+f_{0} T\right) \\
& =V_{b} \cos 2 \pi\left(\dot{f}_{0} T t+f_{0} T\right) \ldots \ldots \ldots \ldots \ldots \ldots \ldots
\end{aligned}
$$

$\left(\dot{f}_{0} T^{2} / 2\right.$ は通常微少であるので無視できる.)

ここで, $V_{t}$ : 送信波電厤の振幅, $V_{r}$ : 受信波電圧の 振 幅,

$V_{h}:$ らり信号電圧の振幅 $\left(=k V_{t} V_{r}\right)$,

$f_{0}$ : 送信波の初期周波数 $(\mathrm{Hz}), k$ : 比例定数,

$\dot{f}_{0}:$ 送信波の周波数变化率 $(\mathrm{Hz} / \mathrm{s})$,

$T=2 x / c$

$x:$ アンテと反射体間の距離 $(\mathrm{m})$

$c$ : マイクロ波伝播速度 $\left(=3 \times 10^{8} \mathrm{~m} / \mathrm{s}\right)$

らなり信号の周波数 $f_{b}$ は (3) 式より,

$$
f_{b}=\dot{f}_{\mathbf{0}} T=2 x \dot{f}_{0} / c
$$

となり，アンテナと反射体間の距離に比例する.

また，らなり信号の電圧の振幅 $V_{b}$ は受信波の電圧に 比例しており，測定対象によるらなり信号電压の振幅を $V_{b s}, \quad$ 測定対象と同一距離に金属板があるときのうなり 信号電压の振幅を $V_{b m}$ として，スラグ面の反射率 $\Gamma_{s}$ を次式で定義した.

$$
\Gamma_{s}=\left(\frac{V_{b s}}{V_{b m}}\right)^{2}=\left(\begin{array}{c}
V_{r s} \\
V_{r m}
\end{array}\right)^{2}
$$

ここで， $V_{r s}, V_{r m}$ はそれぞれ対象がスラグ面，金属 板であるときの受信波電圧の振幅である.

\section{$2 \cdot 2$ 測定装置}

・般に，FM レーダを設計するためには，対象の反射 率を知る必要がある，スラグのマイクロ波反射率を知る ため，2.5 t 試験転炬で予備試験を実施し次の 知見を得 た。

（1）マイクロ波帯における転炉吹鍊中のスラグの反 射率は，金属板の反射率に対して $-47 \mathrm{~dB}$ 程度である. さらに，マイクロ波の伝播損失を考虑すると，受信波の 電力は伝送電力の $-66 \mathrm{~dB}$ 程度になり, きわめて微弱

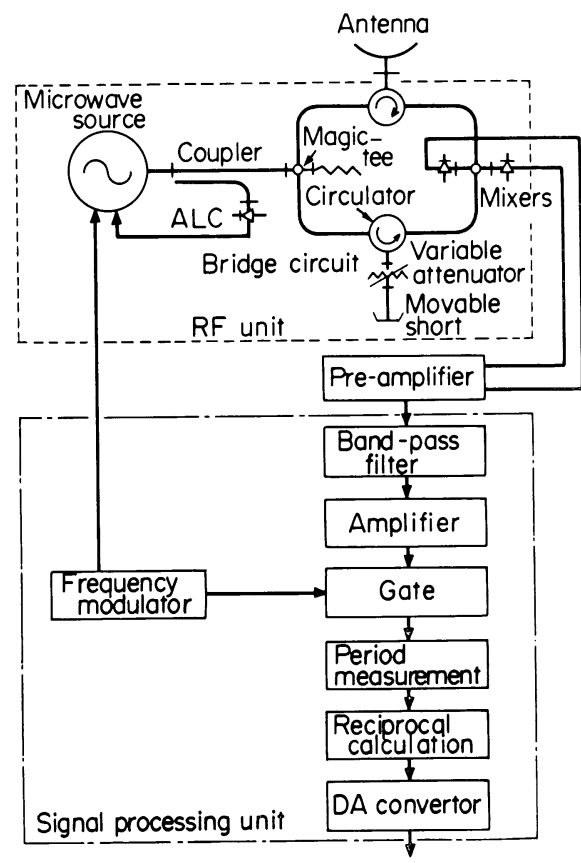

Fig. 2. Block diagram of the microwave slag level gauge.

である。このような微弱電力を検出するため高感度の受 信装置が必要である。

（2）スラグ面からの反射が微弱であるため，スラグ 面以外からのわずかな反射があつても測定の妨害にな る，不要反射の要因は種々考えられるが6)，転炉内久ラ グレベル測定の場合に重要なものは，転炉炉口からのマ イクロ波散乱，マイクロ波回路内の反射であり、これら を極力低い值に押さえる必要がある。

これらの点に留意して測定装㯰を製作した，Fig. 2 にマイクロ波スラグフォーミングレベル測定装置の構成 を示す．本装置はマイク口波アンテナ， RF ニニットお よび信号処理ユニットの部分から構成されている.

\section{$2 \cdot 2 \cdot 1$ マイクロ波アンテナ}

転炉炉口からの不要反射を避けるためには，アンテナ の指向性を鋭くし，マイクロ波ビームが転炉炉口にかか らないよらにする必要がある。必要な指向性を得るた め, 波長 $(\lambda)$ 約 $12.5 \mathrm{~mm}(24 \mathrm{GHz})$ のマイク口波拈 よび内径 (D) $350 \mathrm{~mm}$ のバラボラアンテナを採用した。 アンテナとスラグ面間の距離 $(x)$ は $10 \mathrm{~m}$ 程度であり, マイクロ波ビームの半値角は, アンテナから $6 \mathrm{~m}$ の距 離で 2.60 度, $10 \mathrm{~m}$ の距離で 2.52 度である。転炉炉 口位置は，アンテナから $6 \mathrm{~m}$ の距離で 3.34 度の角度で あり，炬口からの反射を避けるに十分な指向性である。 


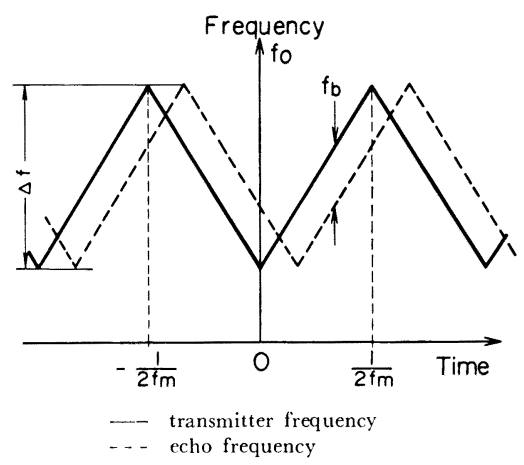

Fig. 3. Triangular modulation.

また, 距離 $10 \mathrm{~m}$ 付近におけるこのアンテナのフレネル ゲインは $36 \mathrm{~dB}$ である.

$2 \cdot 2 \cdot 2 \mathrm{RF}$ ユニット

$\mathrm{RF}$ エニットは, マイクロ波発振器, マイクロ波回路 および検出うなり信号前置増幅器により構成される。 、 イクロ波発振器としては, $10 \mathrm{~mW}$ 出力の $\mathrm{K}$ 帯域半導体 式発振器 (YIG 同調発振器) を使用した.

一方, 微弱な受信波を $\mathrm{SN}$ 比良く計測するため, 平衡 混合器を用いたマイクロ波ブリッジ回路を適用した。す なわち, 平衡混合器により発振器の AM 雑音を抑制する とともに, ブリッジの一端に設けた可動短絡器および可 変減衰器を用いてアンテナからの不要反射を補償した.

\section{$2 \cdot 2 \cdot 3$ 信号処理ユニット}

信号処理二ニットは，うなり信号の周波数を測定し, スラグレベルに対心した出力を得るための信号処理をお こなう部分である。また，らなり信号の強度を測定し， スラグの反射鿌に対忍した出力を同時に得る.

周波数変調は，Fig. 3 に示すよらな三角波变調方式 を採用した：三角波変調の場合, らなり周波数 $f_{b}$ は次 式で表わされる。

$$
\left.f_{b}=2 \cdot f_{m} \cdot\right\lrcorner f \cdot T=\frac{\left.4 \cdot x \cdot f_{m} \cdot\right\lrcorner f}{C}
$$

ここに, $f_{m}$ : 変調周波数, $\Delta f$ : 变調周波数带域であ り，それぞれ， $f_{m}=100 \mathrm{~Hz}, \Delta f=300 \mathrm{MHz}$ を用いた。

信号処理装㯰は精度向上のため以下のくらうを施し た.

(1) 一般にFM レーダでは, 周波数カウンタでう なり信号の周波数を求める場合, 固定䛊差を生じる5

三角波変調の場合の固定䛊差 $\delta \mathrm{R}$ は次式で示される.

$$
\delta R=\frac{c}{4 \cdot\lrcorner f}
$$

固定䛊差の影響を蔵少させるためには, 变調周波数帯 域 $J f$ を増大させれば良いが，これには実際上限界があ

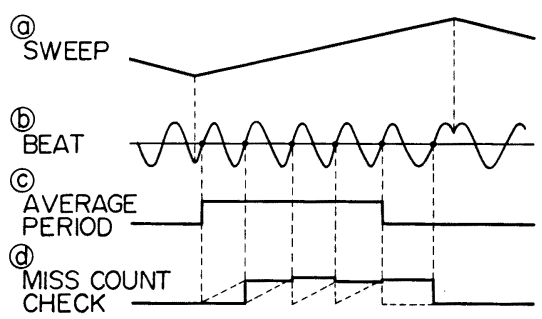

Fig. 4. Ideal waveforms in the signal processing unit.

る.そこで，各変調周期ごとに三角波の折り返し点から 離れた個所でのらなり信号のN周期の平均值を測定し, その逆数演算をおこなう力式を採用した，概念図をFig. 4 に示す. @は二角波变調信号であり, それに対応して 得られるらなり信号(bの零点を検出して, N周期 (Fig. 4 では 4 周期) 分の時間幅を持つパルス(C)を得る.この パルスの時間幅を計数し，逆数演算によりらなり信号の 周波数に対㤁した出力を得る. (dは， N周期のうなり信 号のおの括のの周期に応じた電生波形を示す周期チェッ ク信号であり，計測值の異常検出に用いる.

（2）転炉吹錬中はうなり信号波形が正弦波形よりく ずれる場合がある。そのために生じる距離測定䛊差を除 くために，周期チェック信号のおのおのの周期に対㐫し た電圧を比較し，その変動が・定值を越える場合には， 真の周期より長い計測值が得られるので, 直前の距離測 定值を保持するような論理回路を付加した，信号波形の 一例を Photo. 1 に示す. (1)は正常な場合, (2) はなり 信号波形がくずれた場合の例である. 写真中矢印で示し た部分でらなり信号波形がくずれ，零点の検出が正常に なされていないため, 周期チェック信号の電生が大きく 変動している. この場合は直前の距離測定值を保持す z.

（3）らなり信号の振幅が一定值より小さくなつた場 合, (2) と同様に直前の距離測定值を保持する論理回路 を付加した。

\section{$2 \cdot 2 \cdot 4$ 距離測定精度}

スラグの反射率が $-47 \mathrm{~dB}$ 程度と微弱であるため, スラグの反射率に近い，マイクロ波吸収体を対象物とし て距離測定試験をおこなつた。使用したマイクロ波吸収 体は， $0.6 \times 0.6 \mathrm{~m}$ の市販品 (Eccosorb-AN 797)) であ り, 反射率は $-32 \mathrm{~dB}$ であつた。測定結果を Fig. 5 に示す.

距離測定範囲 5〜15 m で精度 $38 \mathrm{~mm}$ の計測が 可能 である. 
(1) (a)

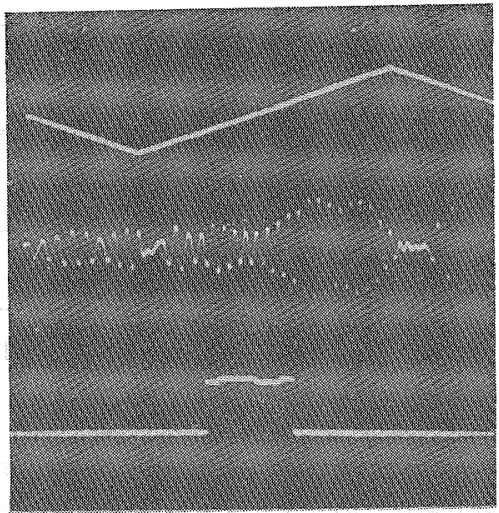

(2)

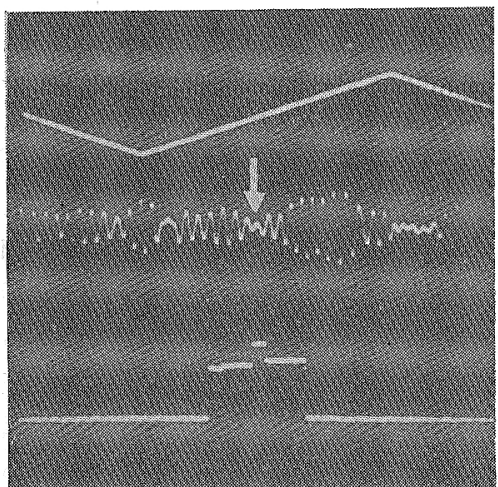

(a) Sweep signal (b) Beat signal

(c) Miss count check signal

Photo. 1. Typical waveforms of miss count check logic.

Target: Microwave absorber $0.6 \mathrm{~m}^{\Phi}$ (Eccosorb: AN 79)

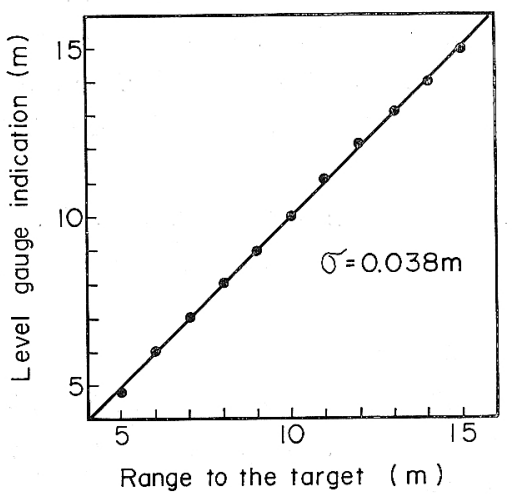

Fig. 5. Accuracy of level gauge.

\section{3. 試 験 方 法}

マイクロ波スラグフォーミングレベル測定装置を当社 和歌山製鉄所第 2 製鋼工場 No. 1 転炉 $(150 \mathrm{t})$ 飞設置 し，以下の試験を括こなつた。
（1）スラグレベル，スラグ反射率とスロッピングの 関係調查.

(2) スラグ反射率とスラグ成分の関係調査.

（3）マイクロ波測定値に基くスロッピング防止試 験.

測定装置の設置状沉を Fig. 6 に示す。 パラボラアン テナは転炉上部フードに設けた微測孔（ジャケット）に 取り付けられ，防熱，防麼対策として水冷特よび窒素パ ージを施した。、マイクロ波発振器，マイクロ波回路など

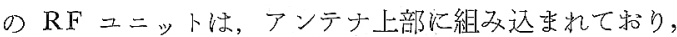
装置の総重量は約 $300 \mathrm{~kg}$ で洒る. (Photo. 2)

信号処理ユニットの出力は計算機に取り込李れ, デー タロギングに朋いら尚とともに，スラグレベル定カラ

- GRT 上に模式的に表示し，オペレータガイドとし て使用できるよらにしている。CRT 画面の例家 Photo. 3 に示吉.

吹鍊中のスロッピングの癹生は目視推察により判定記 録した。おた，スラグレベル測定精度の確認，扣よびス ラグ㳯化状態の指標を得るために，サブランスを用いた スラグレベルの間欠湘定劣よびスラグサンプルの採取を 和こなつた、サブランススよるスラグレベル測定は，サ ブランス先端に取り付けた電極が導通したとさのサブラ ンス位置を検出することにより括こなつた。

\section{4. 測定結果と考察}

\section{1 スロッピングとスラグレベル，スラグ 反射率との} 関係

本装置以よるスラグレベル，スラグ反射率の測定結果 例を.Fig. 7 に示す．（a）は吹鍊中にスロッピングが観 察された場合，（）性観察されなかった場合の例であ る。スラグレベルは炻ロレベルを基集として，末たスう

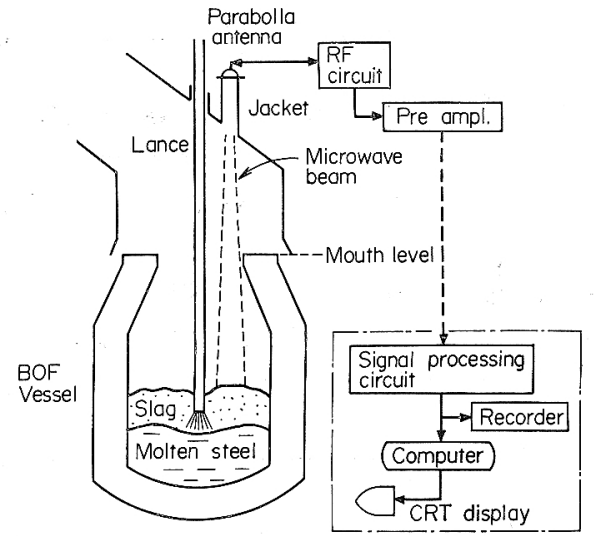

Fig. 6. Schematic diagram of the installation. 
Lance

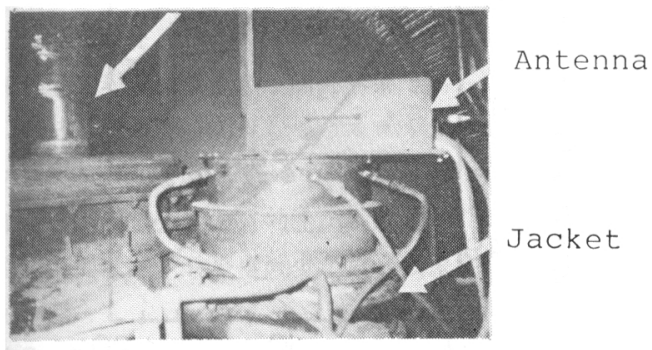

Photo. 2. Microwave antenna.

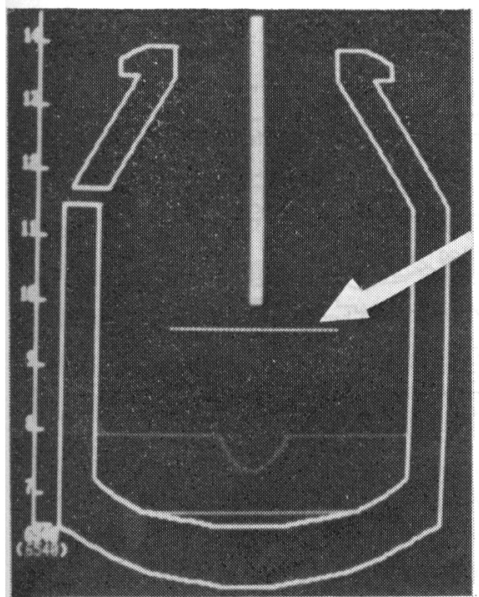

Photo. 3. CRT display.

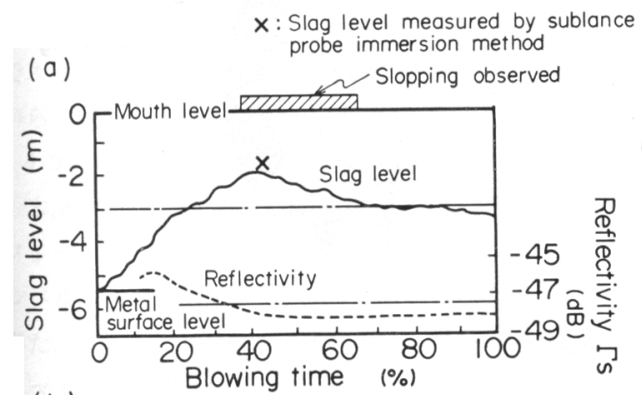

(b)

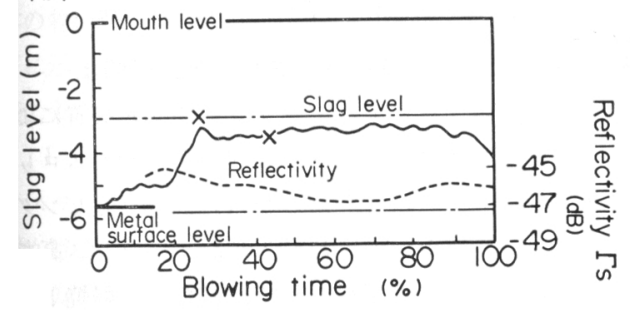

Fig. 7. Typical results of measurement during BOF operation.

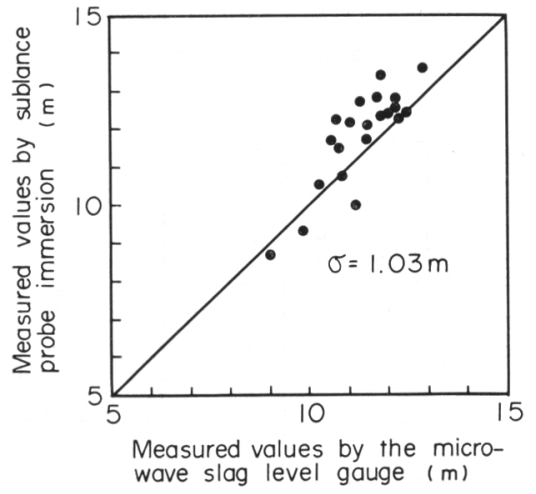

Fig. 8. Comparison of the microwave method with the sublance probe immersion method.

グ反射率は $2 \cdot 1$ で示したように金属板による反射を基 準として表した.

吹鍊開始前は溶銑レベルを示しており, 吹錬開始後, 鋼浴面上にスラグが形成され, 吹錬進行に伴いスラグレ ベルが変化する状況が良好に測定されている，サブラン スによるスラグレベル間欠測定の結果との対応も，Fig. 7 (図中×印) 拈よび Fig. 8 に示すように十分であつ た.

Fig. 7 の (a), (b) 両者を比較すると, (a) は全 般的にスラグレベルが高く，スラグ反射率が低い。 た，スロッピングはスラグレベルが特に高くなつた時点 で生じている.

以上のことから，スラグレベル，スラグ反射率ともに スロッピングの発生と密接な関係にあることがわかつ た.

また, 吹錬開始前の炉底, 湯面の測定が可能である。

\section{$4 \cdot 2$ スロッピングの予知}

スロッピング発生時に抮けるスラグレベル，スラグ反 射率の分布を, 非スロッピング時と比較した結果をFig. 9 に示す. スロッピングの有無によりスラグレベル，ス ラダ反射率とも明らかな差があるが, 完全には分離して 特らず，これらの測定值を用いてスロッピングを予知す る場合にはある程度の過検出を伴ら。

そこで, 約 30 回の吹錬の測定結果をもとに統計処理 を扣こない, 過検出率を一定值以下に押さ光, 乙かもス ロッピング予知率を最大にする予知レベルの検討を抏こ なつた. ここで, 過検出率, スロッピング予知率は以下 の定義による值である。

$$
\text { 過検出率 }=\frac{\text { スロッピング非発生機会 }}{\text { スロッピング予知機会 }}
$$



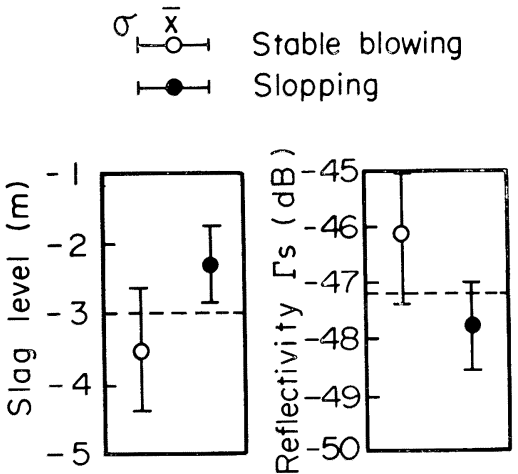

Fig. 9. Slag level and reflectivity versus slopping.

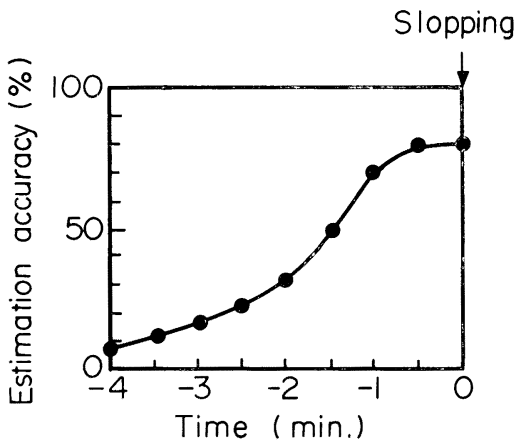

Fig. 10. Estimation accuracy of slopping.

スロッピング予知率 $=\begin{aligned} & \text { スロッピング発生機会 } \\ & \text { メロッピング尒知機会 }\end{aligned}$

検討の結果，スラグレベルが炉口から $-3 \mathrm{~m}$ 以上に 上昇し，かつスラグ反射涪が $-47.2 \mathrm{~dB}$ 以卜になつた 時を，スロッピング予知範井に没定した。この設定にお ける大ロッピング予知流の奏績を Fig. 10 に示す.

スロッピング発生 $1 \mathrm{~min}$ 前に 70\% 以上, $30 \mathrm{~s}$ 前に は 80\% 以上の確率でスロッピングの予知が可能であ りまたここの時の過検出率は $20 \%$ 以下である.

上記設定值に基き，スロッピング予知時にはカラー CRT 上に警報を出すようにした。

\section{$4 \cdot 3$ スラグ成分とスラグ反射率の関係}

転炉吹錬中にサブランスを用いたスラグサンプリンク を扣こない，スラグ成分と久ラグ妏射率の関係を調枯し た．スラグ中 T.Fe とスラグ反射率の関係を Fig. 11 に示す。 スラグは T.Fe が增加する程スラグ反射糸は 弱くなるといら良好な相関が多られた。，スラグ中 $\mathrm{FeO}$ が高い程石死の涬化速度が早いことが知られているの で8)，スラグ反射率は涬化状況の指慓として使用し得る。

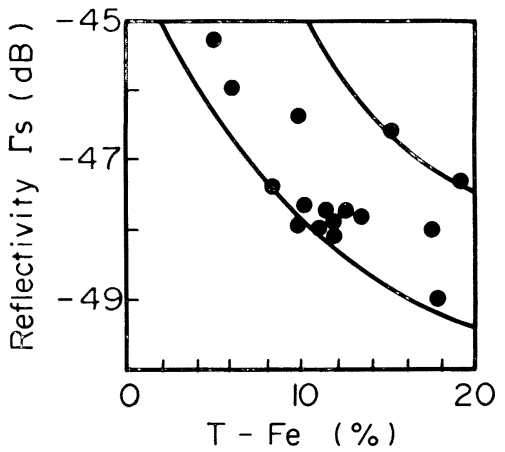

Fig. 11. Relation between $\mathrm{T}-\mathrm{Fe}$ in slag and slag reflectivity.

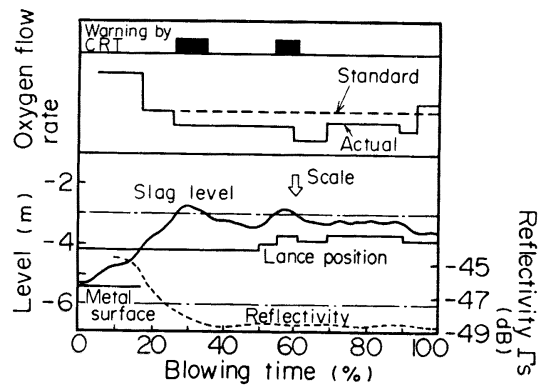

Fig. 12. Typical result of controlled blowing by the microwave slag level gauge.

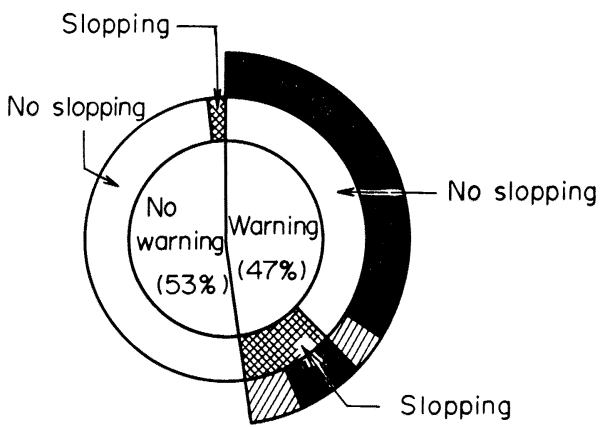

oxygen flow rate control no oxygen flow rate control

Fig. 13. Results of slopping control.

\section{4 マイクロ波測定值に基くスロッピング防止}

アイクロ波入ラグフォーミングレベル测定装置による スロッビング予知に基き久ラグレベルを制御し人ロッヒ

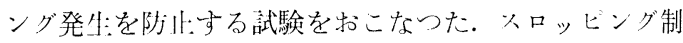

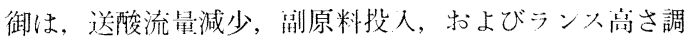
整によりおこない，副原料としては鉄鈆不，軽焼ドロー イトなどを使用した。 スロッピング防止制御の一例を Fig. 12 に示す。 
この例では、久ロッヒング警報に基く送酸流量減少の アクションによりメロッビングを防此するとともに，ラ ンス操作をおこないメラグレベルを一定に保つ制御を䇛 施しており，活ぼ良好な制御結果である。

約 50 回の吹錬に対しての久ロッビング防㤢:制御言武験 の結果を Fig. 13 に亦す。汪注银好な制御がなされて

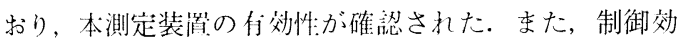
果としては，送酸流最減少が最も效果があるといら結果 を得た。

\section{5 考 察}

4.5.1 大ロッピングと火ラグレベルの関係

スロッピングとスラグレベルの関係は従来より指摘さ

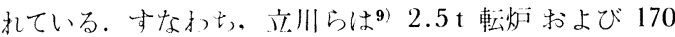
$\mathrm{t}$ 転炉におけるスラグレベルの間久測定により，大ラグ レベルはフォーミングにより吹鍊中期に最も上昇し，転 炉炉口付近まで達しているとの絬果を得た。また，又口 ッピングが、スラグフォーミングおよび軖動最授受によ

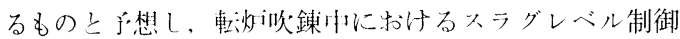
の重要性を指摘している。方，Chernyatevich らは 10)，観測空を没けた $60 \mathrm{~kg}$ 転炉にお打る吹鍊状況の観 察により，久口ッピングの機满を次のよらに考えた。が ス，スラグ扰よびィタルのェマルジョンが激しく形成さ れ，転炉内の広範闻の部分を満た寸結果，それが反応に より生成する $\mathrm{CO}$ ガ火の排出に対しての障害となり, 捕足された $\mathrm{CO} カ ゙$ 人が爆発的に拔け出る時に久ラグ タルエマルジョンを同時に持七出すことによりスロッヒ ングが発特する。

著者らの得た、以ラグレベルが非常に高くなつた時点 でスロッピングが発牳するといら結果は, これらの従来

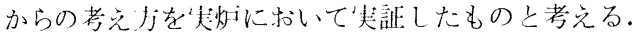

$4 \cdot 5 \cdot 2$ スラグフォーミングと反射絃の関係

本試験によ扎ば，火ラグのマイクロ波文射率はスラグ フォーミングおよび沾化度と相関があり，フォーミング レベルおよび涬化度が高いほど反射摔が低くなる結果を 得た。

マイクロ波を物体に投射した場命の反射率は，対象物 体の物性值および表而状態により変化する，そこで，以

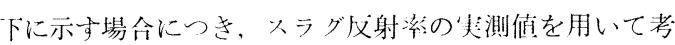
察した。

（1） 火ラグ峳而が粗俑であると考える場合

スラグ表而の凹凹により，一イクロ波が乱文射され， 見かけ、上仅射淬が変化与る場命である。乱文射が起こる ような粗面の条件は, Rayleigh criterion ${ }^{11)}$ にり次式 で与觉らる。

$h>\lambda / 8$. ここで，hは山円の高さ，入はマイクロ波波長であ る.

大ラグ面の単位面積あたりの後方散乱断面積を $っ$ とす ると, 送信電力 $P_{t}$ 之受信電力 $P_{r}$ の此 $\eta_{r}$ は次式で! えられる11)

$$
\eta_{r}=\begin{array}{cc}
P_{r} & \lambda^{2} \\
P_{l} & =(4 \pi)^{3}
\end{array} \int_{r^{4}}^{s} \cdot G^{2} d S
$$

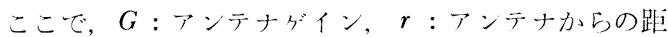
離, $d S:$ : 久ラグ面の単位表面積である。

アンテナ立体解を $\Omega_{0}(=4 \pi / G)$ とし，アンテナ指向 性が十分に鋭く， $r \simeq x$ と考えて良いとすると，

$$
\begin{aligned}
& \eta_{r}=\frac{\lambda^{2}}{(4 \pi)^{3}} \int \begin{array}{c}
s \\
r^{2}
\end{array} G^{2} d \Omega \simeq \begin{array}{cc}
\lambda^{2} & s \\
(4 \pi)^{3} & x^{2}
\end{array} \cdot G^{2} \Omega_{0} \\
& =\left(\begin{array}{c}
\lambda \\
4 \pi
\end{array}\right)^{2} \cdot \begin{array}{c}
s \\
x^{2}
\end{array} \cdot G
\end{aligned}
$$

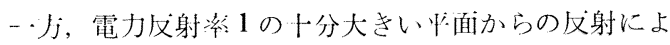
る送受信電力此は次式で少えられる。

$$
\eta_{s}=\left(\begin{array}{c}
\lambda \cdot G \\
8 \pi x
\end{array}\right)^{2}
$$

したがのて（5）式の足義に基げく火ラグ謝率は次 式で与えられる。

$$
\Gamma_{s}=\begin{aligned}
& \eta_{r} \\
& \eta_{s}
\end{aligned}-\frac{4 s}{G}
$$

とくに，粗面の周期が波言 $\lambda$ にくべて十分大きい，ラ ンダム粗而の後力散乱断面積 $s$ は次式で方光られる

$$
s=\exp \left[-\left(\begin{array}{c}
4 \pi \rho \\
\lambda
\end{array}\right)^{2}\right]
$$

ここで, $\rho:$ 表而粗さの標準偏差である.

今可の奏測値， $\Gamma_{s}=-47 \mathrm{~dB}, \lambda=12.5 \mathrm{~mm}, G=36 \mathrm{~dB}$ より $\rho$ を逆算すると， $\rho=1.97 \mathrm{~mm}$ を得る。この考えが 正しいか否かを検䞑するため，X带のマイクロ波を用い て転炉大ラグの反射䅴を胡測した場命の結果と比較し た. X带での測定の結果を Fig. 14 に示す. 試験条件 は Table 1 のとおりである。

$\rho$ のX带からの推定值は $6.36 \mathrm{~mm}$ であり, K帯のも のと大幅に異なる．以上より，粗面からの乱反射により スラグ反射率が決定されているとは考えにくい。

（2）スラグの物性值によると考える場合

$h<\lambda / 8$ ，すなおり，（8)式が成立しないときには，ス ラグ面はマイクロ波文射に関しては平面とみなして良 W.

空気(インピーダン火 $\left.Z_{0}\right)$ と大ラグ（インピーダン火 $Z$ ）の平面境界にマイクロ波を投射した場合の反射滀は 次式で表される。

$$
\Gamma_{s}=\frac{Z-Z_{0}^{2}}{Z+Z_{0}}
$$




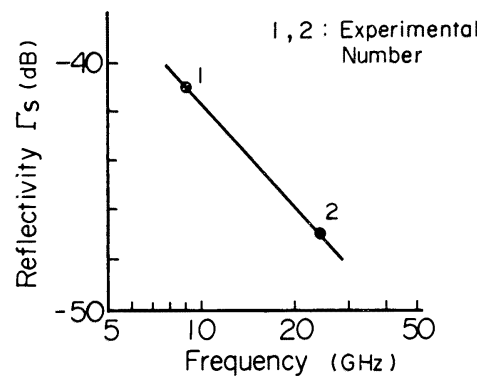

Fig. 14. Refrectivity of the slag v.s. frequency.

Table 1. Experimental conditions.

\begin{tabular}{|c|c|c|}
\hline No. & 1 & 2 \\
\hline \hline Microwave Frequency & $9 \mathrm{GHz}$ & $24 \mathrm{GHz}$ \\
\hline Wavelength & $33.3 \mathrm{~mm}$ & $12.5 \mathrm{~mm}$ \\
\hline Antenna Diameter & $230 \mathrm{~mm}$ & $350 \mathrm{~mm}$ \\
\hline Antenna Gain & $22.0 \mathrm{~dB}$ & $36.0 \mathrm{~dB}$ \\
\hline
\end{tabular}

$$
Z_{0}=\sqrt{\varepsilon_{\varepsilon_{0}}^{\mu_{0}}}, Z=\sqrt{\mu_{\varepsilon_{r} \varepsilon_{0}-j \frac{\sigma}{\omega}}^{\mu_{0}}}
$$

ここで, $\varepsilon_{0}:$ 真空の誘電率 $\left(=8.85 \times 10^{-12} \mathrm{~F} / \mathrm{m}\right)$

$\mu_{0}:$ 真空の透磁率 $\left(=4 \pi \times 10^{-7} \mathrm{H} / \mathrm{m}\right)$

$\omega:$ マイクロ波角周波数

$\varepsilon_{r}:$ スラグの比誘電溹

$\sigma:$ スラグの電気伝導度 $(\sigma / \mathrm{m})$ である.

（14）式に（15）式を代入して, 次式を得る.

$$
\Gamma_{s}=\left[\left(1-\sqrt{\varepsilon_{r}-j \frac{\sigma}{\omega \varepsilon_{0}}}\right) /\left(1+\sqrt{\varepsilon_{r}-j \frac{\sigma}{\omega \varepsilon_{0}}}\right)\right]^{2}
$$

(16) 式を用いて実測反射率よりスラグの電気伝導度 $\sigma$ を逆算する（16)式で $\sigma$ が正の值を持つためには， $\varepsilon_{r} \leq$ 1.03 である必要があるので, 一応 $\varepsilon_{r}=1$ として $\sigma$ を求 めると， $\sigma=0.2 \sim 0.36(\sigma / \mathrm{m})$ となる. 一方, $\mathrm{CaO}-\mathrm{FeO}$ $-\mathrm{SiO}_{2}$ 系スラグの電気伝導度の文献値は $3 \sim 20 \% / \mathrm{m}$ の 範囲であり，また， $\mathrm{FeO}$ が高くなるにつれて電気伝導 度が高くなることが示されている13). (16)式は, 電父伝 導度が高い汪ど反射染が高くなることを示して打り，

$\mathrm{FeO}$ が高いほど反射率が低ドする Fig. 11 の結果と矛 盾する。

以上より，スラグの反射率をスラグ物性值の変化のみ により説明することは困難である。

そこで，スラグと $\mathrm{CO}$ 父泡の混在により複合物質と してふるまら場合を考光る。なおち，内部に含有する $\mathrm{CO}$ 気泡径がマイクロ波波长にくらべて小さい場合，ス
ラグと気泡の混合物はマイクロ波的には一様な物質とし

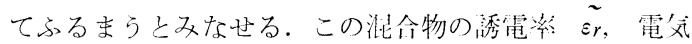
伝導度 $\tilde{\sigma}$ は次式で表されると仮定する。

$$
\tilde{\varepsilon_{r}}-j \frac{\tilde{\sigma}}{\omega}=(1-\xi) \varepsilon_{0}+\xi\left(\varepsilon_{r} \varepsilon_{0}-j \frac{\sigma}{\omega}\right)
$$

ここで， $\xi:$ スラグの体積淬である.

$\varepsilon_{r}=1$ と仮定すると， $\tilde{\varepsilon}_{r}=\varepsilon_{\mathbf{0}}$ となるので，取射率 $\Gamma_{s}$ は次式で表される。

$$
\Gamma_{s}=\left[\left(1-\sqrt{1-j} \frac{\xi \sigma}{\omega \varepsilon_{0}}\right) /\left(1+\sqrt{1-j} \frac{\xi \sigma}{\omega \varepsilon_{0}}\right)\right]^{2}
$$

スラグ反射率の実測值と，副原料投入量とスラグレベ ルより概算したスラグの体積淬 $(\xi=0.08 \sim 0.14)$ を用 いて，(18)式より推定されるスラグの笔気伝導度 $\sigma$ は, 2〜5( $/ \mathrm{J} / \mathrm{m})$ となり，核文献值 ${ }^{13)}$ と一致する。

以上のことから，スラグの反射棌は， スラグ表面が $\mathrm{CO}$ ガス気泡を含んだ気液混合体となることにより低下 すると推定され，フォーミングレベル打よび涬化度が高 い程, $\mathrm{CO}$ ガス気泡の占める割命が増加し, 反射率が低 くなる現象を示すと推察される。しかし，CO ガス気泡 の大きさやスラグ中での CO ガス分布の影響，扣よび スラグの比誘電凉 $\varepsilon_{r}$ は不明であるため，火ラグのマイ クロ波片射率と涬化度が対灾古る機構については, 今後 の検討課題としたい.

\section{5. オンライン使用結果}

以上の結果に基き，マイクロ波スラグフォーミングレ ベル測定装置をオペレータガイドとするオンライン使用 を执こなつている，CRT に警報が表示された時点で， 送酸量減少, 副原料投入の制御を一定基準を決好て実施 している. オンライン使用の効果を Fig. 15 に示す.

マイクロ波測定装置を使用した場命のスロッピング発 生頻度は，非使用時の約 $1 / 5$ 飞減少して抢り，明らか な効果が認められる。一力，スロッピング防止制御の採 用による吹鍊時問の増加は認められずばらつきは減少し ている。

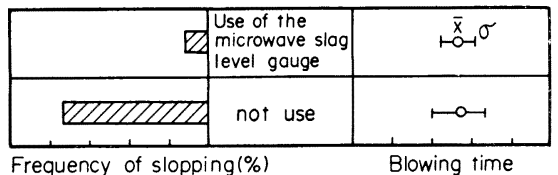

Fig. 15. Effect of on-line use of the microwave slag level gauge. 


\section{6. 結}

\section{$\overline{\overline{\bar{\sigma}}}$}

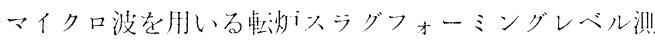

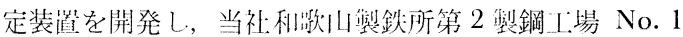
転炉に適用した結果，以トの結論を得た。

（1）スラグレベル，スラグ反射涪の测定により，又 ロッピングの予知が $80 \%$ 以にの確度で可能である。 ま た，過検出棌は $20 \%$ 以下である。

(2) スラグ反射凉と大ラグ洋化状沉との间に相関が ある・

（3）本測定装临に甚くスラグレベル制御が可能であ り。オンライン使用の絬果，又ロッピング発生頻度を約 1/5 に減少することができた.

本装置は現在オンライン使用をされており，スロッピ ング防止を含めた総合的な転炉吹鍊制御法の閒発に活用 することができる。

終わりに，本测定方法の䦌発を扔こならに当たり，終 始御指導をいただいた作龙金風丁:業(怢)技監白㞸俊男 博土，小央技術研究所次長 梅目洋一正，和歌川製鉄所 製鋼部垃梨和 甫上Eに感谢致します。また，同製鉄所 岸开速比には，現場適用に阙して，栗林 隆比には， 計算機によるデータ処理に关して全闻的に協力していた

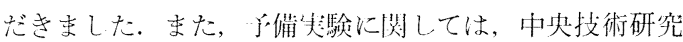

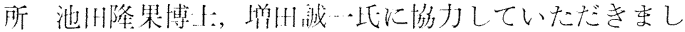

た.

\section{文献}

$1)$ R. Holper and E. Denis : C. N. R. M. Metallurgical Report, 17 (1968), p. 11

2) P. DAuby and $J$. Lückers : B. O. T. Reports (1973)

3 ) 古垭一成，松永 久，富永忠男，荒不英夫，瀬野 昭夫，山本静夫：鉄と鋼，64 (1978)，S 570

4) 飯田義治，大森 尚，大西正久，平山勝久，竹内 巧：鉄之鋼，64 (1978), S 172

5 ) M. I. Skolnik : Introduction to Radar Systems (1962), p. 86, p. 95 [McGraw-Hill]

6 ) $M$. Capelli : Radio Altimeter, I. R. E. Trans., Vol. ANE-1, (1954) 2, p. 3

7 ) Emerson \& Cumming, Inc. 技術資料 No. 8-2-4

8 ）第 3 版 鉄鋼便覧 II 製銑製鋼（日本鉄鋼協会編） (1979)，p. 469 [丸善]

9 ) 立川正涁, 岛田道彦, 不橋政衛, 白岩惟:光：鉄々 鋼, 60 (1974), A 19

10) A. G. Chernyatevich, E. Ya. Zarvin, Yu. $N$. Borisov, and $M$. I. Volovich : Steel in USSR, (1976), p. 544

11) $P$. Beckmann and $A$. Spizzichino: The Scattering of Electromagnetic Waves from Rough Surfaces (1963), p. 9, p. 398, p. 80 [Pergamon Press]

12) Stratton : Electro magnetic Theory (1941), p. 283 [McGraw-Hill]

13）特別報告書 No. 12 溶鉄・溶滓の物性值便覧（溶 鋼・溶浮激会繧）（1971），p.270[日本鉄鋼協会] 